\title{
Microclimate and development of Coffea canephora cv. Conilon under different shading levels promoted by Australian cedar (Toona ciliata M. Roem. var. Australis)
}

\author{
Gleison Oliosi ${ }^{1}$, João Antonio Dutra Giles ${ }^{1}$, Weverton Pereira Rodrigues ${ }^{2}$, José Cochicho Ramalho ${ }^{3,4}$, \\ Fábio Luiz Partelli*1
}

${ }^{1}$ Centro Universitário Norte do Espírito Santo (CEUNES), Universidade Federal do Espírito Santo (UFES), São

Mateus, ES, Brazil

${ }^{2}$ Centro de Ciências e Tecnologias Agropecuárias, Universidade Estadual do Norte Fluminense Darcy Ribeiro

(UENF), Parque Califórnia, Campos dos Goytacazes, RJ, Brazil

${ }^{3}$ Grupo Interações Planta-Ambiente \& Biodiversidade (PlantStress\&Biodiversity), Linking Landscape,

Environment, Agriculture and Food, (LEAF), Dept. Recursos Naturais, Ambiente e Território (DRAT), Instituto

Superior de Agronomia (ISA), Universidade de Lisboa (ULisboa), Oeiras, Portugal.

${ }^{4}$ GeoBioTec, Faculdade de Ciências Tecnologia, Universidade Nova Lisboa (FCT/UNL), Caparica, Portugal

*Corresponding author: partelli@yahoo.com.br

\begin{abstract}
Coffee growers are searching for more sustainable production systems. Shaded cultivation is presented as a management option to attenuate coffee environmental stresses. This work aims at to evaluate the microclimate and coffee plant (Coffea canephora cv. Conilon Clone 02) development under different shading levels promoted by the intercropping with Australian cedar (Toona ciliata M. Roem. var. Australis) or under unshaded conditions. Australian cedar and Conilon coffee were planted in $15 \times 2 \mathrm{~m}$ and $3 \times 1.2 \mathrm{~m}$ spacing, respectively, resulting in five rows of coffee to one row of Australian cedar. The closer the coffee rows were in relation to the Australian cedar trees the higher shade level was obtained. Climatic variables (temperature, irradiance and relative humidity) and leaf areas were evaluated over four seasons, and the internode lengths of plagiotropic and orthotropic branches were evaluated monthly. The 2013yield was also measured. There was a decrease in both the irradiance and temperature and an increase in the relative humidity at all times under shaded cultivation (closer to the Australian cedar row). The highest growth of plagiotropic and orthotropic branches and leaf expansion were found under shaded cultivation; however, the number of nodes per branch and the yields were similar among treatments. Growing Conilon coffee intercropped with Australian cedar showed a good yield potential.
\end{abstract}

Keywords: Agroforestry systems; Coffea canephora; Intercrop; Toona ciliata.

Introduction

The Coffea genus includes at least 124 species (Davis et al., 2011), among which Coffea arabica L. and C. canephora Pierre ex A. Froehner are the most important in economic terms. Brazil is the largest producer and exporter of coffee (ICO, 2015), but with a huge social-economic importance of this crop in the tropical area. The Australian cedar (Toona ciliata M. Roem.) belongs to the Meliaceae family, naturally occurring from India and Malaysia to northern Australia (Lorenzi et al., 2003). Australian cedar exhibits rapid growth and high-quality wood and can be used together with coffee to diversify production, distributing the economic return over the year and providing a better utilization of the area (Müller et al., 2004). Coffee is often subjected to supra optimal temperatures that sometimes exceed $38{ }^{\circ} \mathrm{C}$ during the critical grain filling phase (Partelli et al., 2010; 2013; 2014b). These conditions, coupled with the occurrence of strong winds and high rates of evapotranspiration, can be stressful to the crop, requiring different management techniques to mitigate these problems (Partelli et al., 2014a). In addition, temperatures above $35{ }^{\circ} \mathrm{C}$, particularly if associated with a prolonged dry season, will increase the probability of sterile flower formation (Camargo and Camargo, 2001) and increase flower abortion (Camargo, 2010) and flower burning before anthesis, affecting as well the germination and pollen tube growth and consequently ovary fertilization, reducing fruit production (Custódio et al., 2014). Finally, high temperatures during bean development are usually related to a loss of quality and impact at beverage level (Santos et al., 2015). Mitigation of climate constraints could be promoted by coffee shaded cultivation (Pezzopane et al., 2010; Pezzopane et al., 2011; Partelli et al., 2014a). In fact, it was reported that coffee plants grown under shaded systems greater physiological potential for carbon gain, and better photosynthetic performance than those grown exposed to full sunlight, producing larger grains with improved organoleptic quality of the grains. Furthermore, lower climate variables pressure was found under shaded cultivation, and lower incidence of Cercospora coffeicola (Bote and Struik, 2011; Steiman et al., 2011; Baliza et al., 2012). Australian cedar trees could contribute to the greater protection of coffee plants against cold winds, frost, high temperatures and excessive irradiance (Morais et al., 2007; Pezzopane et al., 2010). Furthermore, shaded systems can be a valuable tool for mitigating the effects of climate changes (Camargo, 2010) 
predicted by the Intergovernmental Panel on Climate Change, or IPCC (IPCC, 2014). Therefore, intercropping coffee in order to generate moderate shading systems improves environmental sustainability, increases the stability of crop production by mitigating potentially stressful conditions, and allows the farmers to obtain other economic important products (DaMatta et al., 2007).

The objective of this study was to evaluate the microclimate and development of Conilon coffee that was subjected to different shading levels by Australian cedar trees along the year in order the clarify the potential usefulness of this intercropping approach.

\section{Results and Discussion}

\section{Microclimate characterization}

Australian cedar trees promoted a reduction of the irradiance incidence at coffee leaf level. The full sun exposed coffee plants showed higher average irradiance values at all year periods, both with southern and northern orientation in relation to the Australian cedar row. However, the observed irradiance exposure depended on the distance to the Australian cedar row, the northern or southern position of the row, and the time of day or year (Fig. 1 and 2). These results corroborate those obtained by Partelli et al. (2014a) on Conilon coffee shaded by rubber trees (Hevea brasiliensis). On winter time (Fig. 1A), there were lower irradiance values for the coffee rows located on the southern side (both on T1 and $\mathrm{T} 2$ distances), with average intercepts of $49 \%$ and $46 \%$, respectively, for incident irradiance. The northern treatments presented interceptions of 38\% (T1) and 35\% (T2). That was mostly related to the lower irradiance values reaching the plants in the morning, due to irradiance interception by the cedar trees, although some differences were present also along the rest of the day. In the spring (Fig. 1B), the T1 southern, T2 southern, T1 northern and T2 northern treatments showed average irradiance intercepts of $51 \%$, $29 \%, 40 \%$ and $52 \%$, respectively. These resulted from the variations in irradiance values throughout the day under different distances to the cedar trees, with the coffee row located close to Australian cedar on the southern side (T1 southern) showing lower irradiance values at certain times of the day. During the summer (Fig. 1C), the lowest irradiance incidence was foundT1 northern, but all treatments presented significant lower irradiance levels in comparison to T3. The interception average ranged between $70 \%$ ( $\mathrm{T} 1$ northern) and $46 \%$ (T2 northern).Considering the daily irradiance during the summer (Fig. 2C), there were lower values throughout the day for the coffee row located close to the Australian cedar on the T1 northern. The coffee rows that were located $4.5 \mathrm{~m}$ from the Australian cedar (T2) on the northern side showed high irradiance values in the morning, similar to those observed on the unshaded coffee rows (T3 unshaded). However, in the mid of the day and partly on the afternoon those values strongly decreased on $\mathrm{T} 2$ in comparison to $\mathrm{T} 3$. The coffeeT1 and T2 treatments on the southern side showed lower values in the morning, reaching similar levels to those located in unshaded rows (T3 unshaded) in the late afternoon. This observed variation throughout the day under different shading levels is a function of the sun position. Martins et al. (2013) observed that shaded coffee leaves showed an overinvestment in photosynthetic machinery, enabling the coffee to cope with rapid exposure to high irradiance under shaded conditions. During the autumn (Fig. 1D), there lower irradiance values were found on both $\mathrm{T} 1$ and $\mathrm{T} 2$ of the southern side, with average interceptions of the incident irradiance of $63 \%$ and $61 \%$, respectively. The $\mathrm{T} 1$ and $\mathrm{T} 2$ treatments on the northern side presented interceptions of $41 \%$ and $31 \%$, respectively. With respect to the daily irradiance (Fig. 2D), the lowest values occurred during the early hours of the day under Australian cedar trees, quite similar to what was observed for winter conditions (Fig.1A and $2 \mathrm{~A}$ ).

Conilon coffee shaded systems with macadamia (Macadamia integrifolia) and coconut (Cocus nucifera L), presented as well as reduced lower radiation levels on the rows close to the shading trees, which promoted strong irradiance interception and caused changes in the environment microclimate conditions (Pezzopane et al., 2010; 2011). Furthermore, C. arabica and shading promoted by Inga densiflora in Costa Rica (Siles et al., 2010) showed greater coffee fruit quality and plant biomass up to threefold compared with a monoculture. On the other hand, a radiation interception of $50 \%$ on shaded C. arabica did not caused changes in the growth, maturation, production and grain size (Morais et al., 2009). The photosynthetic light saturation is generally $c a .600 \mu \mathrm{mol} \mathrm{m} \mathrm{m}^{-2} \mathrm{~s}^{-1}$ for sun-grown and $c a .300$

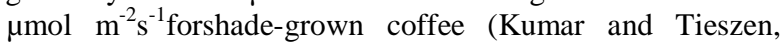
1980; Fahl et al., 1994; Martins et al., 2014). Therefore, the average intercept of $47 \%$ observed in this work is within the range proposed by those authors. Studies on arabica coffee grown under agroforestry systems have shown limitations for both stomatal conductance and light availability for coffee photosynthesis under shade levels above $45 \%$ (Franck and Vaast, 2009). Carelli et al. (1999) observed significant reductions in photosynthesis and stomatal conductance with light interception of $80 \%$; however, they found no differences in these variables with a light interception of $50 \%$. On the other hand, Ronquim et al. (2006) reported that arabica coffee leaves experience up to threefold increase in their daily net photosynthesis under $c a$. $800-1,100 \mu \mathrm{mol} \mathrm{m}^{-2} \mathrm{~s}^{-1}$ irradiance and $c a$. $0.5-2.5 \mathrm{kPa}$ vapour pressure. Shading by Australian cedar trees promoted a reduction in the average daily temperature for all periods. In fact, full sun exposed coffee plants (T3 unshaded) showed the highest temperature values, although the difference changed with $\mathrm{T} 1$ and $\mathrm{T} 2$ treatments (distance to shading tree), with southern/northern orientation and along the year (Fig. 3 and 4), what would be closely related to the irradiance at leaf level (Fig. 1). On winter season, a reduction of $0.7^{\circ} \mathrm{C}$ of the average daily temperature was observed on both distances (T1 and T2) of the southern side, when compared to T3 plants (Fig. 3A). For northern orientation the average reduction reached $0.2(\mathrm{~T} 1)$ and $0.4{ }^{\circ} \mathrm{C}$ (T2), significantly only for the latter. These average differences will mostly related to the lower temperature values in the early morning, since afterwards the temperatures tended to be similar among treatments throughout the day (Fig. 4A). During spring (Fig. 3B) the daily average temperatures showed the minimal differences amongst all treatments for the entire year. Although with some statistical differences, the differences to T3 plants ranged only from $0.1{ }^{\circ} \mathrm{C}$ (T1 northern) to $0.4{ }^{\circ} \mathrm{C}$ (T1southern), what agrees with the large overlapping of daily temperature patterns (Fig. 4B). The quite modest differences between $\mathrm{T} 3$ and all the other shaded treatments on both winter and spring would be associated with the lower leaf area index of Australian cedar, since it is a deciduous tree (Lorenzi et al., 2003). During summer season (Fig. 3C), the temperature differences between $\mathrm{T} 3$ and the shaded treatments, mainly in the $\mathrm{T} 1$ plants (closer to the Australian cedar), were enlarged. T1 northern and T1 southern showed mean daily temperatures reductions of 3.5 and $2.8{ }^{\circ} \mathrm{C}$, respectively, whereas $\mathrm{T} 2$ southern and $\mathrm{T} 2$ northern values decreased 1.3 and $1.0{ }^{\circ} \mathrm{C}$, respectively. These differences were related to lower temperature values observed in the 

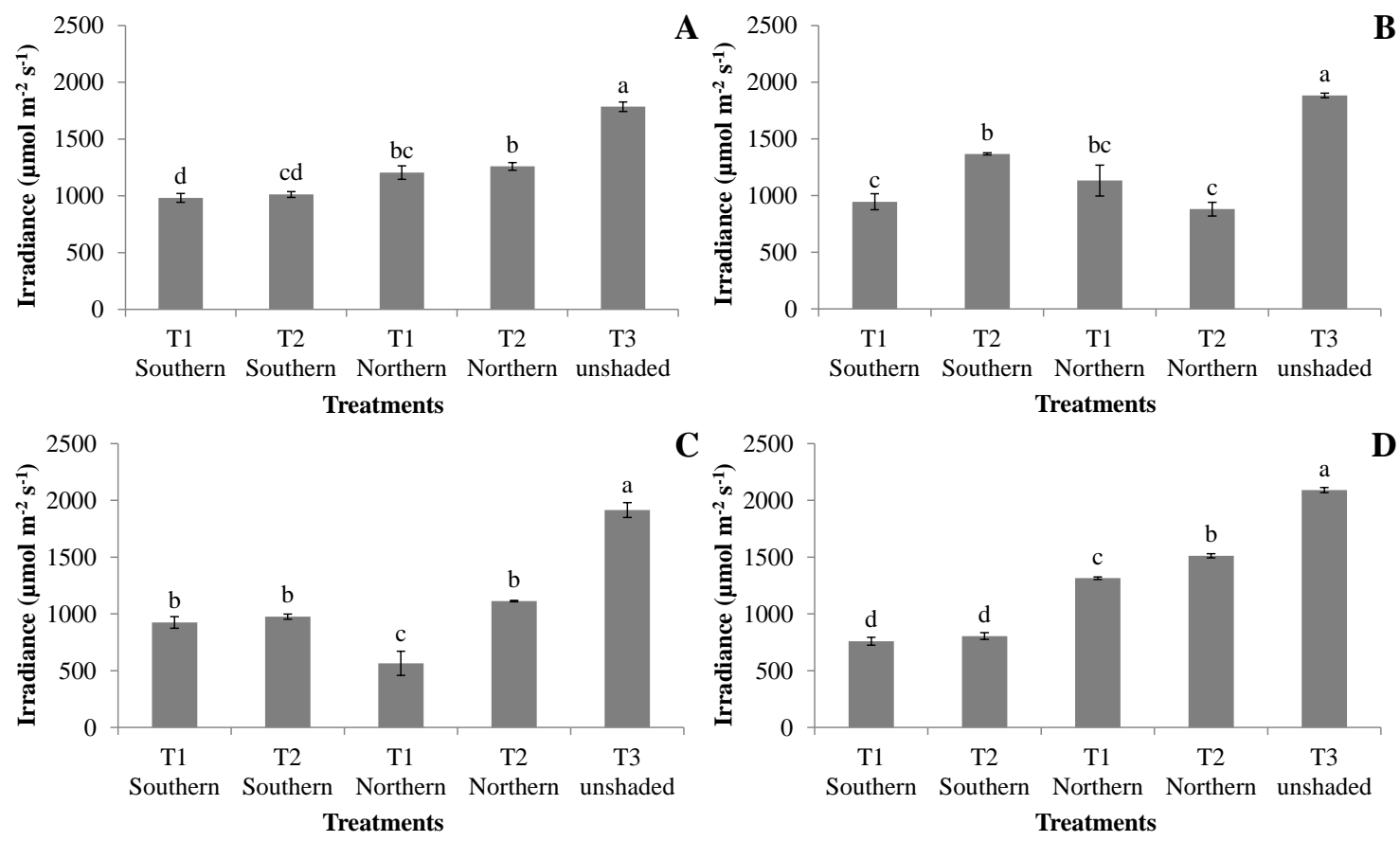

Fig 1. Average daily irradiance during the winter (A), spring (B), summer (C) and autumn (D) on conilon coffee that was grown in the shade under Australian cedar in which the coffee row was located $1.5 \mathrm{~m}$ from Australian cedar on the southern side (T1 southern) or on the northern side (T1 northern), a coffee row at $4.5 \mathrm{~m}$ on the southern side (T2 southern) and the northern side (T2 northern), and an unshaded coffee row (T3 unshaded). Vertical bars represent the standard error of mean. Bars followed by the same letter do not differ by Tukey's test at $5 \%$. CV\%: winter $=5.84 \%$; spring $=9.69 \%$; summer $=9.72 \%$; and autumn $=3.30 \%$.
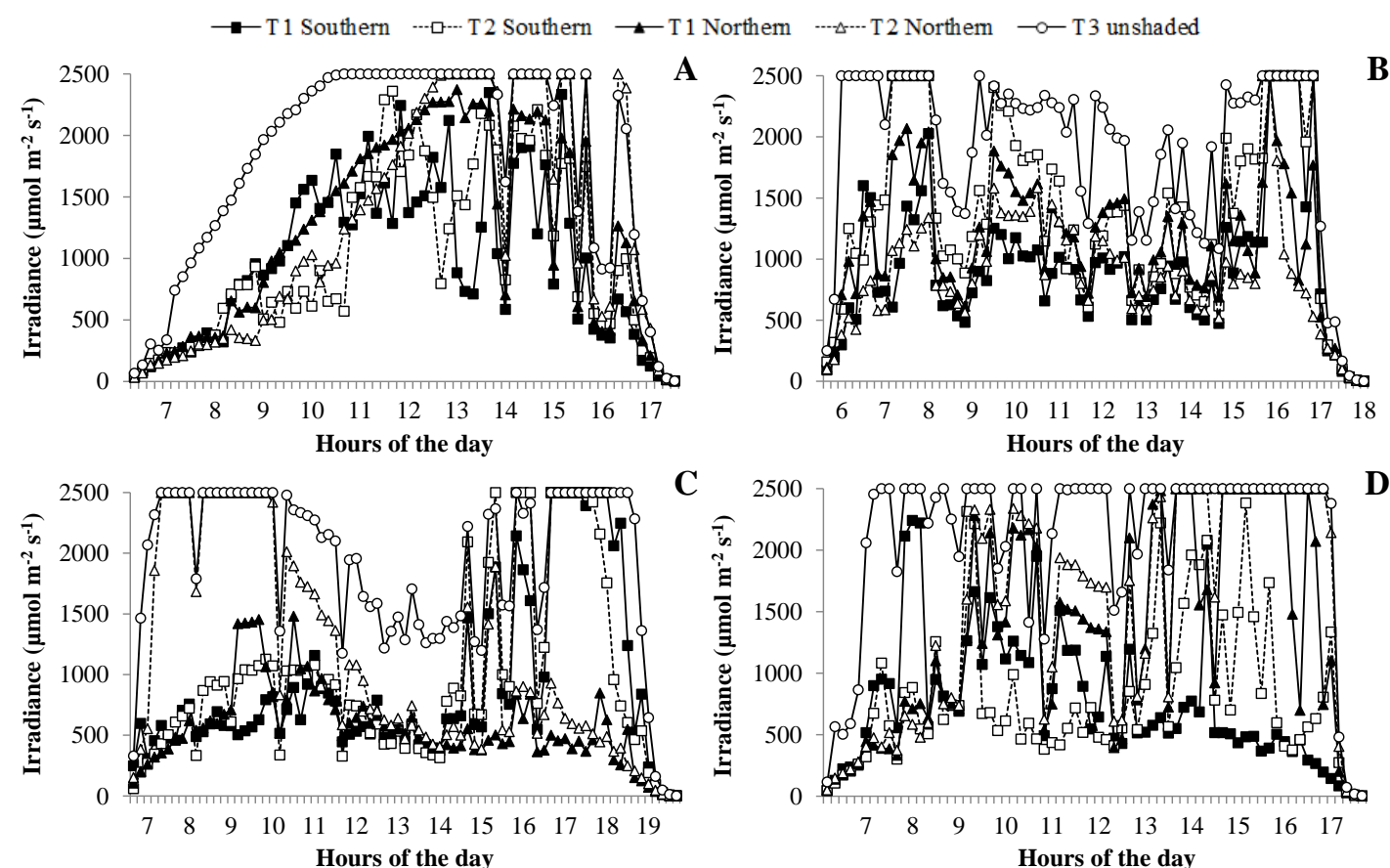

Fig 2. Average daily irradiance values during the winter (A), spring (B), summer (C) and autumn (D) in conilon coffee shaded by Australian cedar for a coffee row located $1.5 \mathrm{~m}$ from Australian cedar on the southern side (T1 southern) and on the northern side (T1 northern), a coffee row at $4.5 \mathrm{~m}$ on the southern side (T2 southern) and the northern side (T2 northern), and an unshaded coffee row (T3 unshaded). 

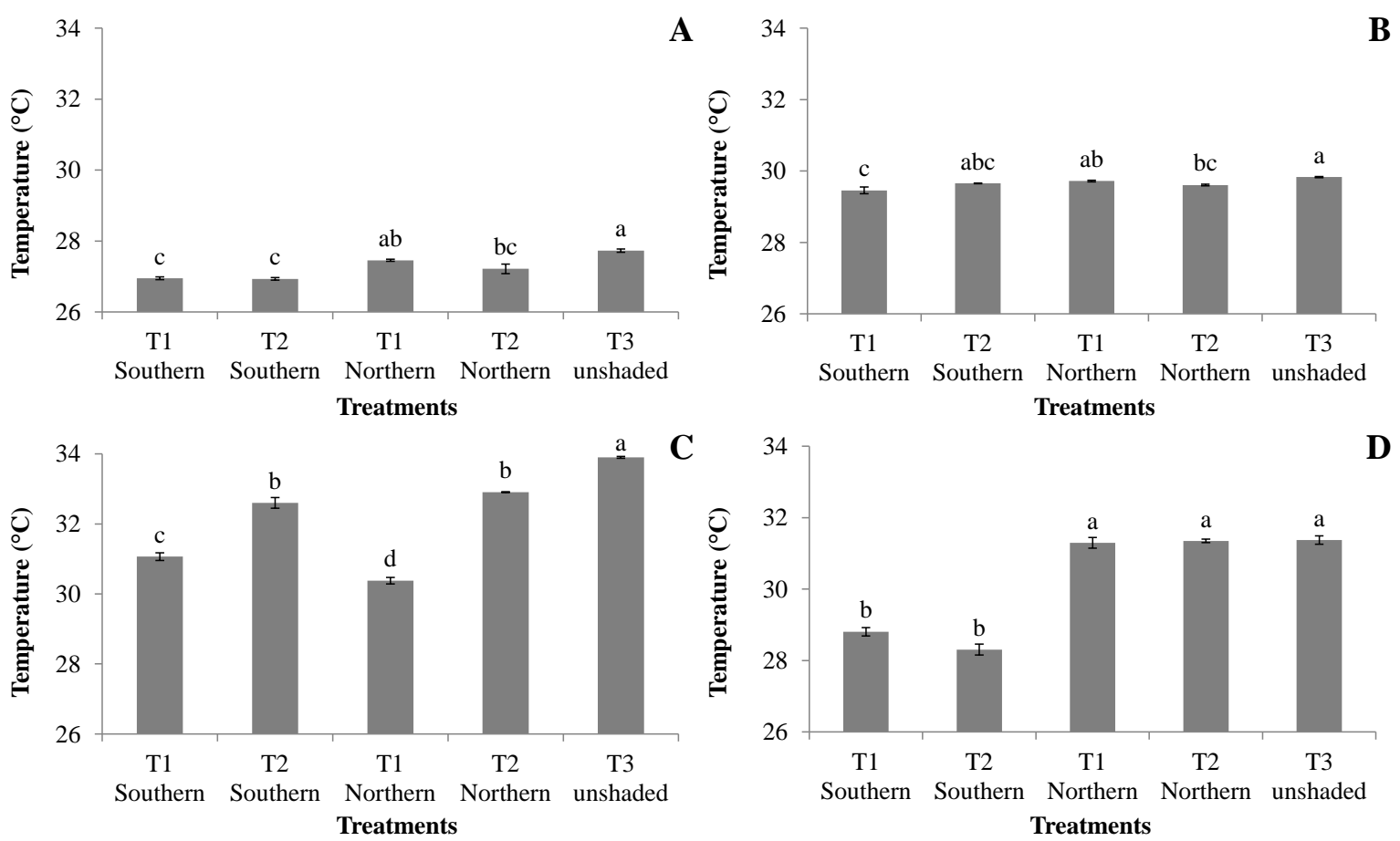

Fig 3. Average daily temperature during the winter (A), spring (B), summer (C) and autumn (D) on conilon coffee that was grown in the shade provided by Australian cedar, with a coffee row located $1.5 \mathrm{~m}$ from Australian cedar on the southern side (T1 southern) and on the northern side (T1 northern),a coffee row at $4.5 \mathrm{~m}$ on the southern side (T2 southern) and the northern side (T2 northern), and an unshaded coffee row (T3 unshaded). Vertical bars represent the standard error of mean. Bars followed by the same letter do not differ by Tukey's test at $5 \%$. CV\%: winter $=0.44 \%$; spring $=0.26 \%$; summer $=0.49 \%$; and autumn $=0.73 \%$.
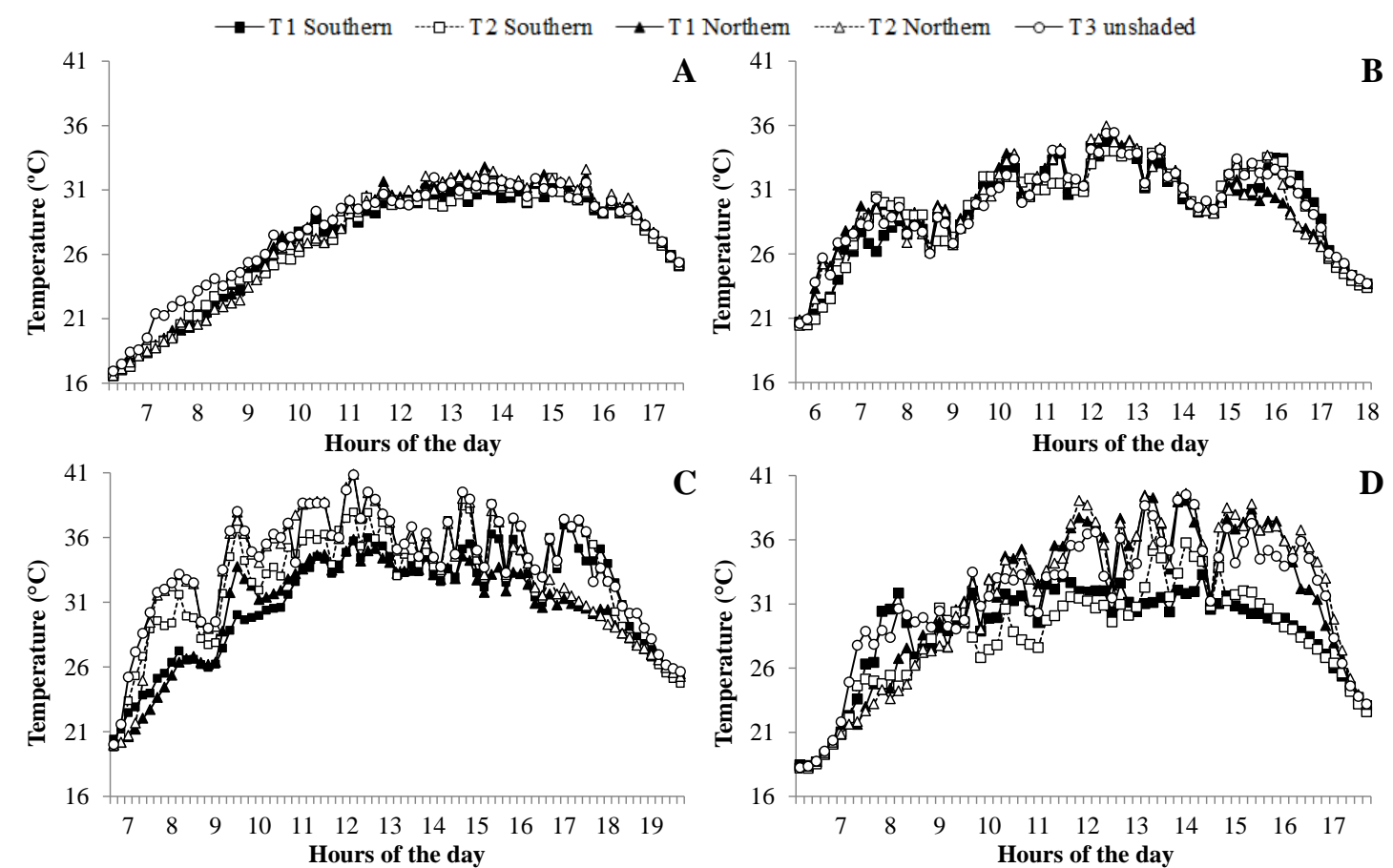

Fig 4. Average daily temperatures in the winter (A), spring (B), summer (C) and autumn (D) on conilon coffee grown in the shade under Australian cedar, with a coffee row located $1.5 \mathrm{~m}$ from Australian cedar on the southern side (T1 southern) and on the northern side (T1 northern), a coffee row at $4.5 \mathrm{~m}$ on the southern side (T2 southern)and the northern side (T2 northern), and an unshaded coffee row (T3 unshaded). 
rows closest to the Australian cedar (T1 northern and T1 southern) in the morning, and also in the northern side (T1 and T2) in the late afternoon (Fig. 4C). This behavioural variation occurs because of the sun's position in relation to the Australian cedar rows. Finally, for autumn measurements (Fig. 3D), lower mean daily temperatures were observed only on the southern side, for bothT1 and T2, with an average reduction of 2.6 and $3.1{ }^{\circ} \mathrm{C}$, respectively, to $\mathrm{T} 3$ treatment. That was related to the lower temperature values found for most of the day in T1 and T2 southern treatments (Fig. 4D). This data are in agreement with the reports that Conilon coffee plants presented temperature decreases up to $6.2{ }^{\circ} \mathrm{C}$ close shading rubber trees (Partelli et al., 2014a), or reductions in air temperature range and leaf and soil temperatures when shaded with Gliricídia (Gliricidia sepium) and Erythrina (Erythrina poeppigiana) (Ricci et al., 2013), resulting in better environmental temperature conditions to the coffee plant. One of the largest reductions in temperature were observed during the summer ( $\mathrm{T} 1$ treatments), when coffee fruiting and higher vegetative growth rates occurred (Partelli et al., 2010; 2013). Therefore, the exposure to average daily temperature reductions of up to $3.5^{\circ} \mathrm{C}$ (Fig. $3 \mathrm{C}$ ) might contribute to mitigate the high temperature effects on the coffee. By this season, supra optimal temperatures of up to $41{ }^{\circ} \mathrm{C}$ were observed (ca 12:10 am) (Fig. 4C), what can disturb to plant metabolic processes and promote leaf damages (DaMatta and Ramalho, 2006).

According to Bunn et al (2015), higher temperatures may imply reduction in area suitable for coffee production. However, Rodrigues et al. (2016) evaluating the interaction of high temperature coupled with the increase of $\mathrm{CO}_{2}$ concentration on Coffea canephora and Coffea arabica, found increasing $\mathrm{CO}_{2}$ concentrations strongly mitigated the effects of high temperatures on the photosynthetic machinery of coffee plants. In what concerns the relative humidity levels (RH), the Australian cedar promoted higher values along the entire year on both distances (T1 and T2) when compared to T3 (Fig. 5). The differences between full sun exposure and shaded treatments were minimal in spring (utmost $2.4 \%$ when compared to $\mathrm{T} 1$ southern) and maximal in summer (up to $10.5 \%$ when compared to T1 northern). Considering the daily $\mathrm{RH}$ values an inversely proportional trend to temperature variations was observed, with higher RH values in the early morning and in the late afternoon and minimal values usually in the middle of the day and early afternoon (Fig. 6). These findings are in line with other reports with shaded Conilon systems, with rubber trees (Partelli et al., 2014a) and macadamia nut trees (Pezzopane et al., 2010). Decreases in temperature, combined with both the maintenance of higher moisture levels in the air and low wind speeds, reduces the water vapour pressure deficit between the leaf and the atmosphere, and, therefore, reduces water loss by transpiration (DaMatta, 2004). Furthermore, these more temperate conditions can allow a greater stomatal aperture, favouring $\mathrm{CO}_{2}$ uptake for photosynthesis without a proportional increase in the transpiration rate (DaMatta and Ramalho, 2006).

\section{Growth evaluation}

The implementation of shade conditions significantly increased the coffee plant leaf area irrespective of the year season (Fig. 7), when compared to unshaded conditions (T3), as also found by others (Ricci et al., 2013). The differences among seasons and orientation side (northern or southern) may be related to both the sun inclination and the irradiance level. Arabica coffee seedlings growth under different radiation levels showed increased leaf area with decreased light (Tabagiba et al., 2010), whereas Conilon plants shaded by rubber trees showed the same pattern of higher leaf area (Partelli et al., 2014a). Valladares et al. (2006) found this effect in different plant species, in which the shaded leaves exhibited increased leaf areas per unit mass because of the lower intensity of received photon flux. According to these authors, the increased leaf area is a plant acclimation strategy under low light for harvesting the greatest possible light intensity. Overall, sun-exposed leaves are smaller because the mesophyll cell arrangement increases the contact surface with the air, allowing better latent heat loss and effective foliar cooling (Rubio-de-Casas et al., 2007). The average internodes length of both plagiotropic/reproductive (Fig.8A and 9A) and orthotropic branches (Fig.8B and 9B) increased throughout the year in response to greater shading levels, as previously reported in coffee trees (Morais et al., 2003; Partelli et al.,2014a). The closer coffee plants to the Australian cedar on the southern side (T1 southern) presented higher internodes lengths in reproductive branches throughout the year (Fig.8A) and from October onwards in orthotropic branches (Fig.8B), likely related to the lower irradiance incidence for most of the evaluated dates (Fig. 1 and 2). In fact, branch elongation is caused by shading to avoid low irradiance (Ricci et al., 2006) or in environments relatively rich in far-red light under low light conditions (Morgan and Smith, 1979). Accompanying the internodes length, also the accumulated branch growth showed variations during the year depending on the different shading levels (Fig.8C, 8D, 9C and D), with increasingly differences starting immediately after the beginning of measurements. When evaluating the cumulative growth data in the last assessment for both orthotropic/reproductive (Fig.9C) and orthotropic branches (Fig.9D), there were increases in these variables according to the increases in shading levels, but there was no significant difference between the non-shadegrown coffee (T3) and the coffee row located $4.5 \mathrm{~m}$ from the Australian cedar on the northern side. The higher growth observed in the shaded plants is similar to the behaviour presented in the branch etiolation (Fig.9A and9B), therefore, the shaded coffee showed the highest growth from internodes elongation that was induced by low irradiance incidence (Fig. 1). Etiolation is not only related to the light quantity but also to the light quality. After passing through the leaves of the Australian cedar canopy, the spectral distribution of solar radiation changed, increasing the far-red ratio compared with the red wavelengths, promoting the conversion of far-red phytochrome into red phytochrome and reducing the ratio between far-red and total phytochrome (Morgan and Smith, 1979). On the other hand, although shade seemed to increase the number of nodes per orthotropic branch (Fig.8E), there were only non-significant changes when considering the entire year (Fig.9E), suggesting similar potential for grain production under different shading levels. In fact, the number of nodes is a good indicator of the amount of productive bud gems available, and it is considered the largest productivity component (Bonomo et al., 2004). Similar numbers of rosettes between both sun-grown and shade-grown coffee were also previously reported by Ricci et al. (2013).Higher nodes values were observed in February in orthotropic coffee branches that were located $4.5 \mathrm{~m}$ from Australian cedar on the southern side (T2 southern) (Fig.8F), differing statistically from coffee that was located $4.5 \mathrm{~m}$ away on the northern side (T2 northern) (Fig.9F). 


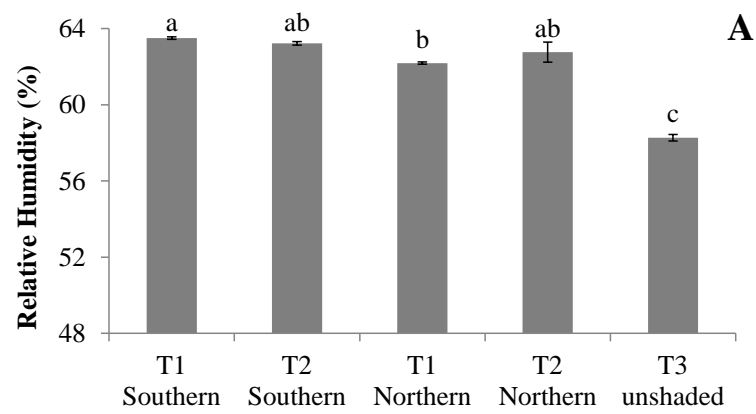

Treatments

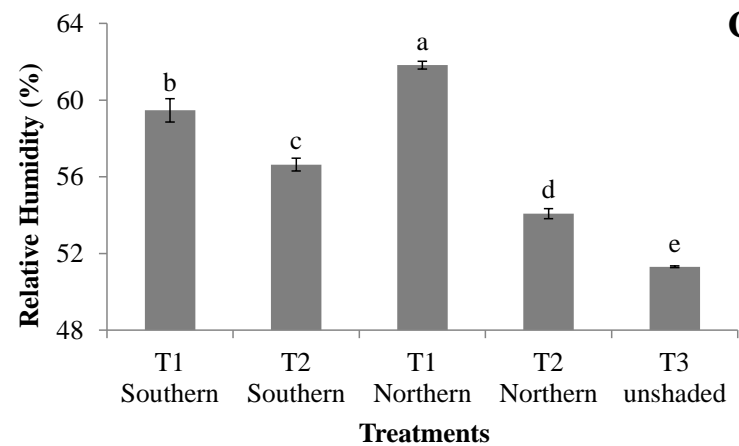

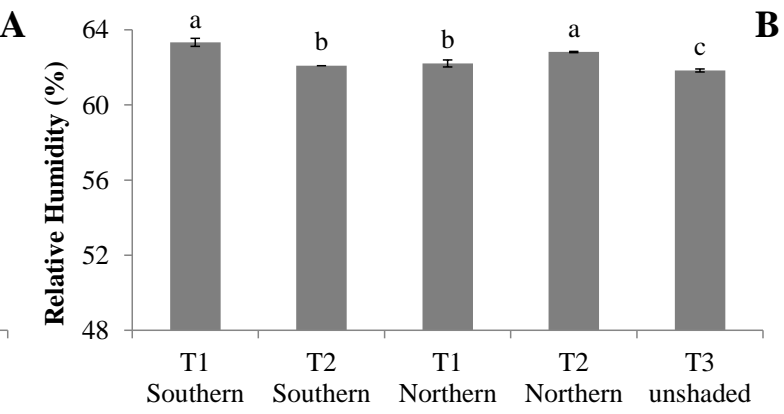

Treataments

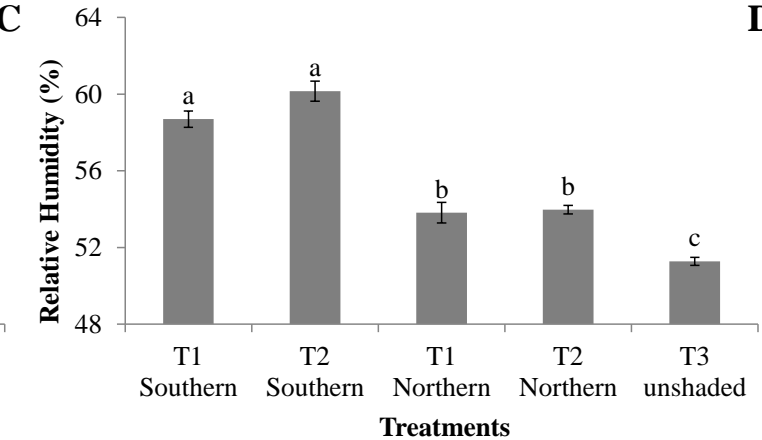

Fig 5. Average relative daily humidity in the winter (A), spring (B), summer (C) and autumn (D) on conilon coffee grown in the shade under Australian cedar, with a coffee row that was $1.5 \mathrm{~m}$ from Australian cedar on the southern side (T1 southern) and on the northern side (T1 northern), a coffee row at $4.5 \mathrm{~m}$ on the southern side (T2 southern) and the northern side (T2 northern), and an unshaded coffee row (T3 unshaded). Vertical bars represent the standard error of mean. Bars followed by the same letter do not differ by Tukey's test at $5 \%$. CV\%: winter $=0.71 \%$; spring $=0.37 \%$; summer $=1.02 \%$; and autumn $=1.26 \%$.
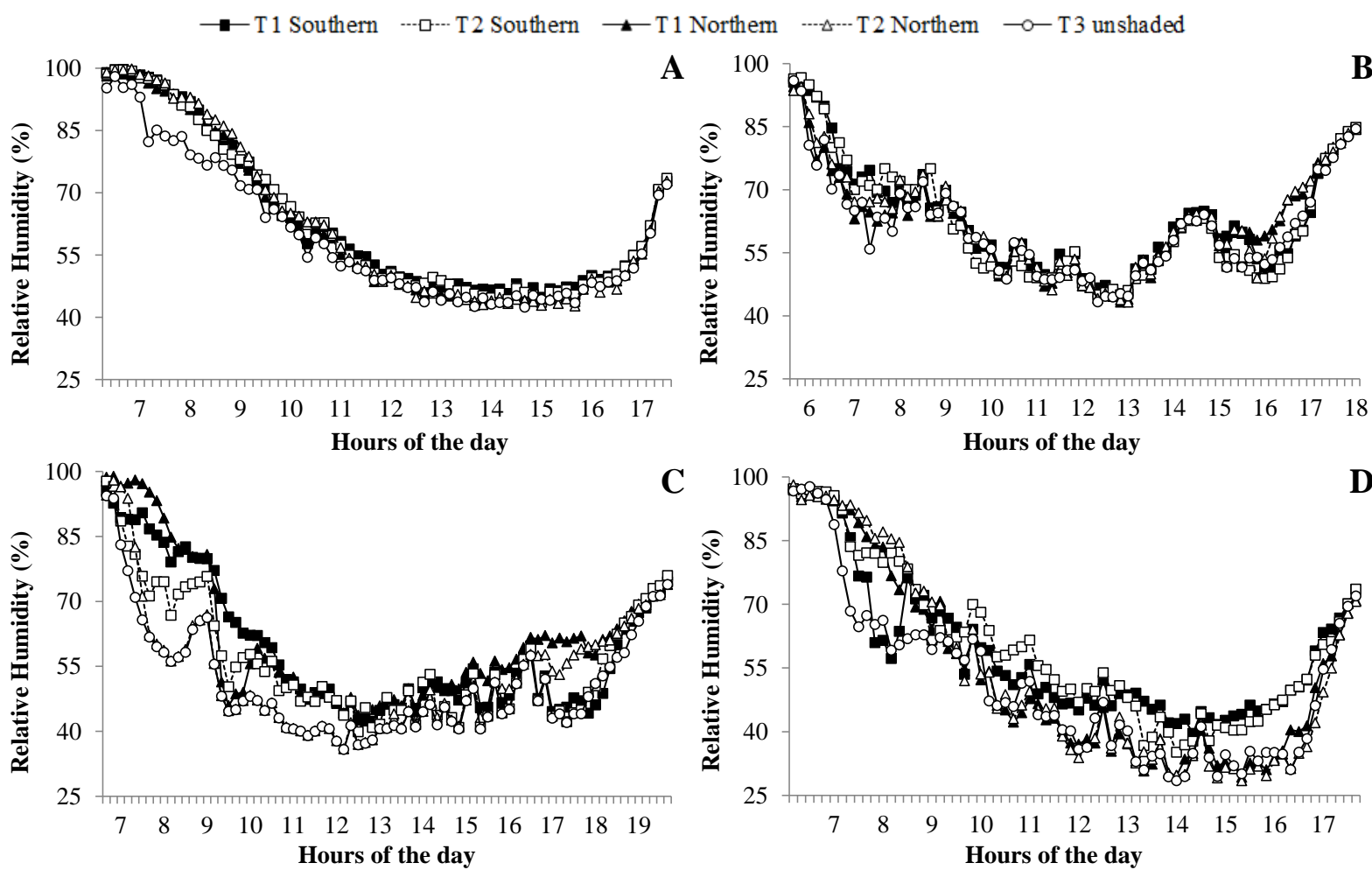

Fig 6. Average daily relative humidity during the winter (A), spring (B), summer (C) and autumn (D) on conilon coffee grown under the shade of Australian cedar with a coffee row at $1.5 \mathrm{~m}$ from the Australian cedar on the southern side (T1 southern) and on the northern side (T1 northern), a coffee row that was $4.5 \mathrm{~m}$ on the southern side (T2 southern) and the northern side (T2 northern), and an unshaded coffee row (T3 unshaded). 

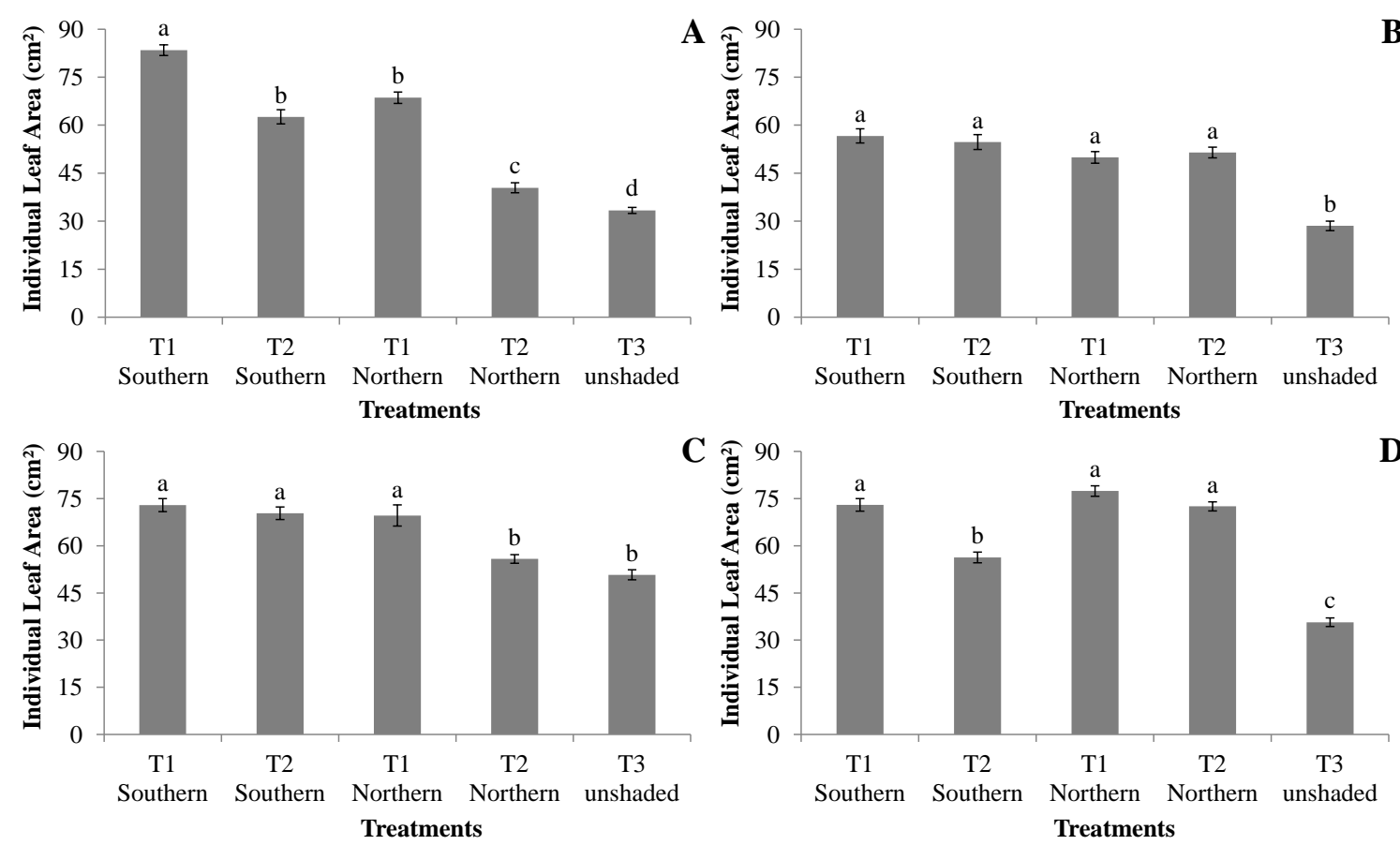

Fig 7. Average individual leaf area in the winter (A), spring (B), summer (C) and autumn (D) on Conilon coffee grown in the shade of Australian cedar with a coffee row located $1.5 \mathrm{~m}$ from Australian cedar on the southern side (T1 southern) and on the northern side (T1 northern), a coffee row at $4.5 \mathrm{~m}$ on the southern side (T2 southern) and the northern side (T2 northern), and an unshaded coffee row (T3 unshaded). Vertical bars represent the standard error of mean. Bars followed by the same letter do not differ by Tukey's test at $5 \%$. CV\%: winter $=20.66 \%$; spring $=28.24 \%$; summer $=24.38 \%$; and autumn $=18.60 \%$.
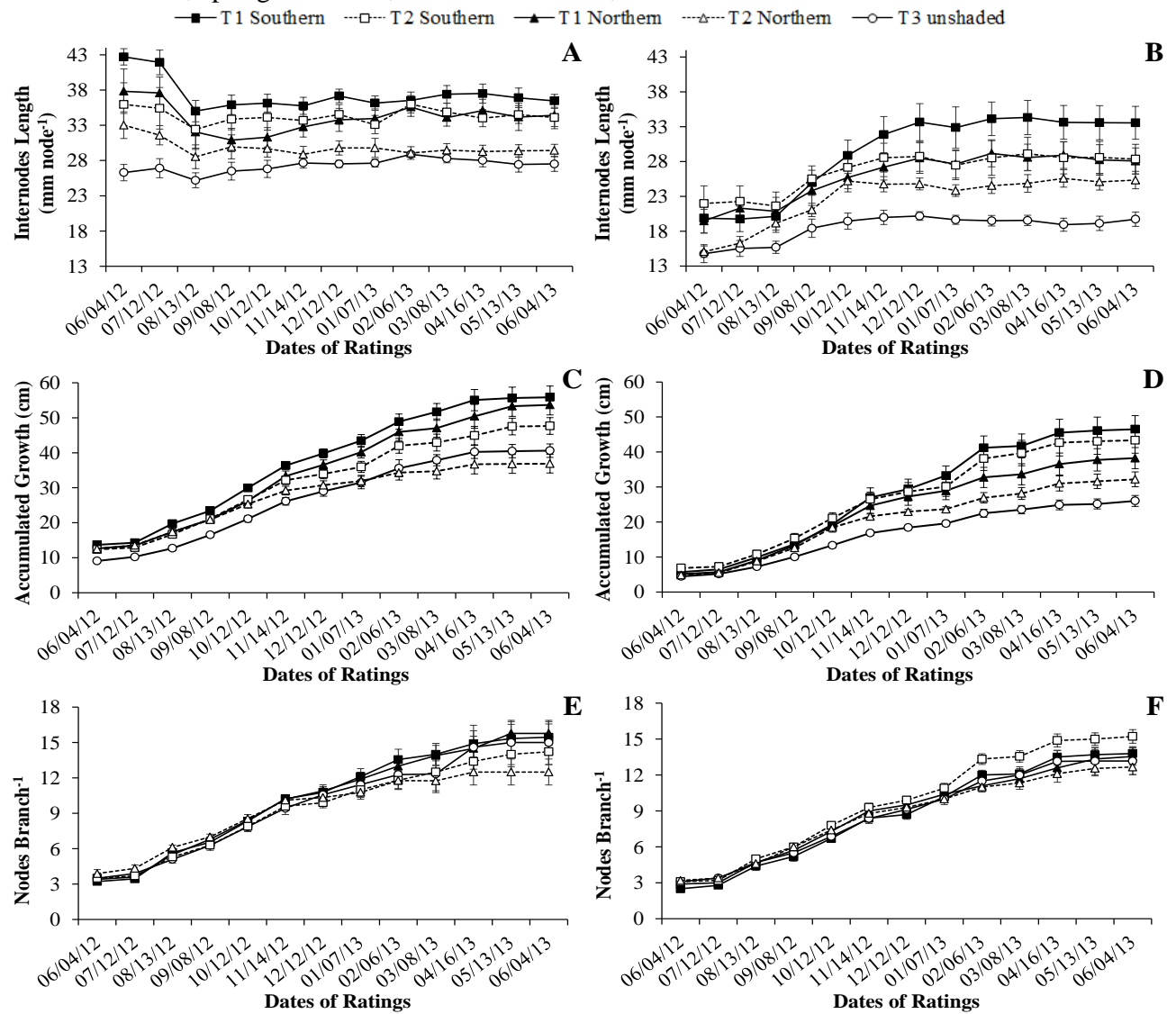

Fig 8. Average internode lengths of plagiotropic/reproductive(A) and orthotropic branches (B), the accumulated growth of plagiotropic/reproductive (C) and orthotropic branches (D), and the number of nodes per plagiotropic/reproductive (E) and orthotropic branches (F) on Conilon coffee grown in the shade of an Australian cedar with a coffee row located $1.5 \mathrm{~m}$ from Australian cedar on the southern side (T1 southern) and on the northern side (T1 northern), a coffee row at $4.5 \mathrm{~m}$ on the southern side (T2 southern) and the northern side (T2 northern), and an unshaded coffee row (T3 unshaded). 

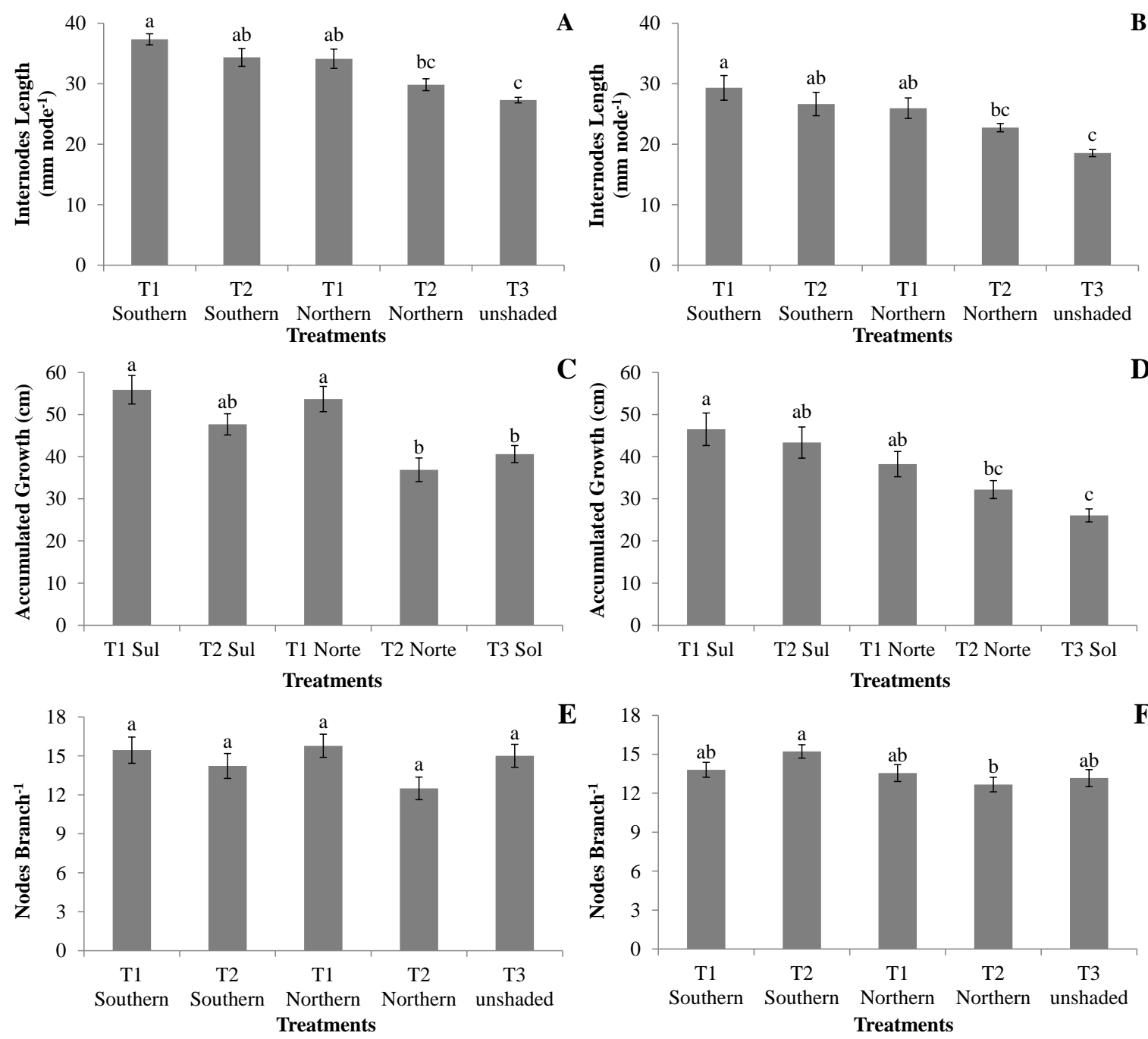

Fig 9. Average internode lengths of reproductive (A) and orthotropic branches (B), the accumulated growth of reproductive (C) and orthotropic branches (D), and the number of nodes per plagiotropic (E) and orthotropic branches (F) on conilon coffee grown in the shade of an Australian cedar with a coffee row located $1.5 \mathrm{~m}$ from Australian cedar on the southern side (T1 southern) and on the northern side (T1 northern), a coffee row at $4.5 \mathrm{~m}$ on the southern side (T2 southern) and the northern side (T2 northern), and an unshaded coffee row (T3 unshaded). Vertical bars represent the standard error of mean. Bars followed by the same letter do not differ by Tukey's test at $5 \%$. CV\%: $\mathrm{A}=11.3 \% ; \mathrm{B}=19.6 \% ; \mathrm{C}=18.7 \% ; \mathrm{D}=25.3 \% ; \mathrm{E}=20.1 \%$; and $\mathrm{F}=13.7 \%$.

\section{Yield}

The shade provided by Australian cedar did not clearly influence the Conilon coffee yield under different shading levels, since it were obtained average yields of $88.44,70.90$, 73.36, 85.51 and 91.15 bags ha $^{-1}$ for T1 southern, T2 southern, $\mathrm{T} 1$ northern, T2 northern and T3unshaded treatments, respectively. Similar results were observed by Partelli et al. (2014a) on Conilon coffee grown shaded by rubber trees under different shading levels. Although coffee grown in agroforestry systems associated with Inga vera and Grevillea robust tress showed higher yields than sun-grown coffee (Salgado et al., 2004), other studies have shown that shade above $80 \%$ decreases the yield (Ricci et al., 2006). It is noteworthy that there was maximum irradiance retention of $70 \%$ in the summer for coffee that was planted $1.5 \mathrm{~m}$ from Australian cedar, which did not influence the coffee yield in the present study. Finally, it is worth noting that on unshaded coffee (T3), the yield was similar to T1 southern, but was clearly higher than $\mathrm{T} 2$ southern and $\mathrm{T} 1$ northern treatments, what agrees with studies showing that coffee is able to cope with excess radiation provide that an adequate mineral nutrition is granted to the plants (Ramalho et al., 1998; 1999; 2000) and it explains the success of sun-grown coffee (Martins et al., 2013). However, it is necessary to emphasize the benefits of a shading system as a cultural management practice that presents the possibility of mitigating the effects of the combined effectsdrought and elevated temperatures on coffee trees (Cavatte et al., 2012). Moreover, this approach allows for the cultivation of two economic relevant crops in the same area, with Australian cedar growing with at reduced cost (data not shown).To determine the economic viability of this intercrop, we will have to account for the cedar harvest and the dilution of revenue through the cultivation years of both species. Therefore, in accounting for both socioeconomic and environmental benefits, this activity has been characterized as a practice that is both viable and sustainable. 


\section{Materials and Methods}

\section{Plant material and experimental design}

The experiment was performed using five years old Coffea canephora Pierre ex A. Froehner cv. Conilon Clone 02 plants, which belongs to the clonal variety "EMCAPA 8111" (Bragança et al., 2001), planted in $3 \times 1.20 \mathrm{~m}$ spacing and watered, on a rural property in São Mateus area, Espírito Santo state, Brazil $\left(18^{\circ} 44^{\prime} \mathrm{S}, 40^{\circ} 14^{\prime} \mathrm{O}\right)$, at $120 \mathrm{~m}$ altitude in flat relief. Together with the coffee plants, were used Toona ciliata M. Roem. var. Australis (Australian cedar), trees with the same age of coffee trees, planted in $15 \times 2 \mathrm{~m}$ spacing, resulting in five rows of coffee to one row of Australian cedar. All rows were oriented $70^{\circ}$ northwest. During the experimental trial period, the Australian cedar presented an average diameter at breast height $(\mathrm{DBH})$ of $c a .50 \mathrm{~cm}$, a height of $c a .12$ meters and a canopy diameter of $c a$. four meters. The experiment consisted of five treatments, with four shading levels, related to the distance to the Australian cedar trees, and one in full sunlight. Two distances of the coffee to the Australian Cedar were considered (T1 at $1.5 \mathrm{~m}$, and $\mathrm{T} 2$ at $4.5 \mathrm{~m}$ ), on both southern and northern sides. The full exposure coffee plants (T3 unshaded) correspond to one coffee row in the adjacent area, without Australian Cedar implantation. The experimental plot consisted of 10 plants (replicates), and measurements of the leaf area, growth, branch etiolation (both on plagiotropic and orthotropic branches), number of nodes per branch, yield assessments and microclimate characterization were performed.

\section{Microclimate characterization}

The microclimate characterization included irradiance, temperature and relative humidity variables. The measurements were performed with an external data logger (HOBO U12, Onset HOBO Data Loggers, Bourne, MA, USA), placed at a $3 \mathrm{~m}$ height above the coffee tree rows and programmed to record data every 10 minutes during every day. Three data logger were placed in each row, resulting in three replicates per treatment. The climatic data were reported on 12/07/2012 (winter), 10/12/2012 (spring), 07/01/2013 (summer) and 04/29/2013 (autumn) between 05:00 and 19:00 on days with full sun. During this time, the apparent movement of the sun was close to $21^{\circ} 48^{\prime \prime}$ northern in the summer to $7^{\circ} 49^{\prime \prime}$ southern in the spring, to $22^{\circ} 15^{\prime}$ " southern in the summer and to $14^{\circ} 44^{\prime \prime}$ northern in the autumn.

\section{Growth evaluation}

Branch measurements were performed monthly for one year $(04 / 06 / 2012$ to $06 / 04 / 2013)$ with a ruler, together with the evaluation of the number of nodes on each marked branch. The average internodes length (etiolation) was obtained by dividing the branch length by the number of nodes.

Maximal length and width of the leaf blade of the leaves used to chlorophyll evaluation were measured, in order to calculate the individual leaf area, according to the Partelli et al. (2006).

\section{Yield}

The harvest of coffee bean was performed manually in 2013 for the 10 plants marked in each treatment. The average coffee seed yield was quantified in litres per plant and extrapolated to bags per hectare by using an assumption of
320 litres of coffee cherries per $60 \mathrm{~kg} \mathrm{bag}^{-1}$ when processed, accounting for yields.

\section{Statistical analysis}

The microclimate, leaf area, relative chlorophyll index and yield data were subjected to an Analysis of Variance and the means were compared by Tukey's test at $5 \%$ probability with the Assistat program (Silva and Azevedo, 2009).

\section{Conclusions}

Shading Conilon coffee with Australian cedar decreased the irradiance and temperature and increased the relative humidity values during the day in most time periods, providing a milder environment for cultivation. This shading led to higher growth and etiolation in both the plagiotropic and orthotropic branches of the coffee trees and higher leaf expansion, demonstrating adaptation to low light, and it did not influence the number of nodes per branch or the coffee yield, although the plants under full sun exposure showed the highest yield values, significantly to some shading treatments. Shading Conilon coffee with Australian cedar under the conditions studied here showed intercropping potential and it simultaneously allows for wood production.

\section{Acknowledgements}

To Coordenação de Aperfeiçoamento de Pessoal de Nível Superior (Capes), Conselho Nacional de Desenvolvimento Científico e Tecnológico $(\mathrm{CNPq})$ and to Universidade Federal do Espírito Santo (UFES), for partial financial support; and to Mr. Wilson Eduardo Tressmann, for allowing the use of the experimental area.

\section{References}

Baliza DP, Cunha RL, Guimarães RJ, Barbosa JPRAD, Avila FW, Passos AMA (2012) Physiological characteristics and development of coffee plants under different shading levels. Rev Bras Cienc Agr. 7(1):37-43.

Bonomo P, Cruz CD, Viana JMS, Pereira AA, Oliveira VR, Carneiro PCS (2004) Evaluation of coffee progenies from crosses of Catuaí Vermelho and Catuaí Amarelo with "Hibrido de Timor" descents. Bragantia. 63:207-219.

Bote ADE, Struik PC (2011) Effects of shade on growth, production and quality of coffee (Coffea arabica) in Ethiopia. J Hortic For. 3(11):336-341.

Bragança SM, Carvalho CHS, Fonseca AFA, Ferrão RG (2001) Clonal varieties of Conilon coffee for the Espírito Santo State, Brazil. Pesqui Agropecu Bras. 36(5):765-770.

Bunn C, Läderach P, Rivera OO, Kirschke D (2015) A bitter cup: climate change profile of global production of Arabica and Robusta coffee. Climatic Change. 129:89-101.

Camargo AP, Camargo MBP (2001) Definition and outline for the phenological phases of arabic coffee under brazilian tropical conditions. Bragantia. 60:65-68.

Camargo MBP (2010)The impact of climatic variability and climate change on arabica coffee crop in Brazil. Bragantia. 69:239-247.

Carelli MLC, Fahl JI, Trivelin PCO, Queiroz-Voltan RB (1999) Carbon isotope discrimination and gas exchange in Coffea species grown under different irradiance regimes. Rev Bras Fisio Veg. 11(2):63-68.

Cavatte PC, Oliveira AAG, Morais LE, Martins SCV, Sanglard LMV, DaMatta FM (2012) Could shading reduce the negative impacts of drought on coffee? A 
morphophysiological analysis. Physiol Plantarum. 144:111122

Custódio AAP, Lemos LB, Mingotte FLC, Barbosa JC, Pollo GZ, Santos HM (2014) Florescimento de cafeeiros sob manejos de irrigação faces de exposição solar e posições na planta. Coffee Sci. 9(2):245-257.

DaMatta FM (2004) Ecophysiological constraints on the production of shaded and unshaded coffee: a review. Field Crop Res. 86:99-114.

DaMatta FM, Ramalho JDC (2006) Impacts of drought and temperature stress on coffee physiology and production: a review. Braz J Plant Physiol. 18(1):55-81.

DaMatta FM, Ronchi CP, Sales EF, Araújo JBS (2007) O café conilon em sistemas agroflorestais. In: Ferrão RG, Fonseca AFA, Bragança SM, Ferrão MAG, Muner LH (Eds.) Café Conilon. Incaper, Vitória.

Davis AP, Tosh J, Ruch N, Fay MF (2011) Growing coffee: Psilanthus (Rubiaceae) subsumed on the basis of molecular and morphological data; implications for the size, morphology, distribution and evolutionary history of Coffea. Bot J Linn Soc. 167:357-377.

Fahl JI, Carelli MLC, Vega J, Magalhães AC (1994)Nitrogen and irradiance levels affecting net photosynthesis and growth of young coffee plants (Coffea arabica L.). J Hortic Sci. 69:161-169.

Franck N, Vaast P (2009) Limitation of coffee leaf photosynthesis by stomatal conductance and light availability under different shade levels.Trees. 23(4):761769.

ICO - International Coffee Organization (2015) Dados Históricos. ICO. Available in: $<$ http://www.ico.org/pt/new_historical_p.asp?section=Estat $\%$ EDstica>.

IPCC. Intergovernmental panel on climate change (2014) Working group III. Mitigation of Climate Change. 99 p. Available

<hhttp://report.mitigation2014.org/drafts/final-draftpostplenary/ipcc_wg3_ar5_finaldraft_postplenary_technical-summary.pdf $>$.

Kumar D, Tieszen LL (1980) Photosynthesis in Coffea arabica. Effects of light and temperature. Exp Agr. 16:1319.

Lorenzi H, Souza HM, Torres MAV, Bacher LB (2003) Árvores exóticas no Brasil: madeireiras, ornamentais e aromáticas. Instituto Plantarum, Nova Odessa, 368 p.

Martins SCV, Araújo WA, Tohge T, Fernie AR, DaMatta FM (2014) In high-light-acclimated coffee plants the metabolic machinery is adjusted to avoid oxidative stress rather than to benefit from extra light enhancement in photosynthetic yield. PLoS One. 9(4):e94862.

Martins SCV, Detmann KC, Reis JV, Pereira LF, Sanglard LMVP, Rogalski M, DaMatta FM (2013) Photosynthetic induction and activity of enzymes related to carbon metabolism: insights into the varying net photosynthesis rates of coffee sun and shade leaves Theor Exp Plant Physiol. 25:63-70.

Morais H, Caramori PH, Koguishi MS, Gomes JC, Ribeiro AMA (2007) Caracterização microclimática de cafeeiros cultivados sob malha de sombreamento e a pleno sol. Rev Bras Agromet. 15(2):133-142.

Morais H, Caramori PH, Koguishi MS, Gomes JC, Ribeiro AMA (2009) Shading of coffee plants during floral buds development and its effects on fructification and production. Cienc Rural. 39(2):400-406.
Morais H, Marur CJ, Caramori PH, Ribeiro AMA, Gomes JC (2003) Physiological characteristics and growth of coffee plants grown under shade of pigeon pea and unshaded. Pesqui Agropecu Bras. 38(10):1131-1137.

Morgan DC, Smith H (1979) Systematic relationship between phytochrome-controlled development and species habitat for plants grown in simulated natural irradiation. Planta. 145(3):253-258.

Müller JS, Gomes MA, Couto L, Pinheiro AL, Alvarenga AP, Lani JL, Vale AB (2004) Sistemas agroflorestais com café (Coffea arabica L.) e Cedro-Australiano (Toona ciliata M. Roem. var. australis (F. Muell.) Bahadur) na Zona da Mata de Minas Gerais: estudo de caso. Agrossilvicultura. 1(1):51-60.

Partelli FL, Araújo AV, Vieira HD, Dias JRM, Menezes LFT, Ramalho JC (2014a) Microclimate and development of 'Conilon' coffee intercropped with rubber trees. Pesqui Agropecu Bras. 49(11):872-881.

Partelli FL, Espindula MC, Marré WB, Vieira HD (2014b) Dry matter and macronutrient accumulation in fruits of Conilon coffee with different ripening cycles. Rev Bras Cienc Solo. 38(1):214-222.

Partelli FL, Marré WB, Falqueto AR, Vieira HD, Cavatte PC (2013) Seasonal vegetative growth in genotypes of Coffea canephora, as related to climatic factors. J Agr Sci. 5:108116.

Partelli FL, Vieira HD, Detmann E, Campostrini E (2006) Estimativa da área foliar do cafeeiro Conilon a partir do comprimento da folha. Rev Ceres. 53(306):204-210.

Partelli FL, Vieira HD, Silva MG, Ramalho JC (2010) Seasonal vegetative growth of different age branches of Conilon coffee tree. Semina: Cienc Agr. 31(3):619-626.

Pezzopane JRM, Marsetti MMS, Ferrari WR, Pezzopane JEM (2011) Microclimatic alterations in a conilon coffee crop grown shaded by green dwarf coconut trees. Rev Cienc Agron. 42(4):865-871.

Pezzopane JRM, Marsetti MMS, Souza JM, Pezzopane JEM (2010) Microclimatic alterations in a conilon coffee crop grown shaded by macadamia nut tree.Cienc Rural. 40(6):17.

Ramalho JC, Campos PS, QuartinVL, Silva MJ, Nunes MA (1999) High irradiance impairments on electron transport, ribulose-1,5-bisphosphate carboxylase/oxygenase and $\mathrm{N}$ assimilation as function of $\mathrm{N}$ availability in Coffea arabica L. plants. J Plant Physiol. 154:319-326.

Ramalho JC, Campos PS, Teixeira M, Nunes MA (1998) Nitrogen dependent changes in antioxidant systems and in fatty acid composition of chloroplast membranes from Coffea arabica L. plants submitted to high irradiance. Plant Sci. 135(2):115-124.

Ramalho JC, Pons T, Groeneveld H, Azinheira HG, Nunes MA (2000) Photosynthetic acclimation to high light conditions in mature leaves of Coffea arabicaL.: role of xanthophylls, quenching mechanisms and nitrogen nutrition. Aust J Plant Physiol. 27:43-51.

Ricci MSF, Cocheto Junior DG, Almeida FFD (2013) Micro weather conditions, phenology and external morphology of Coffee trees in shaded and full sun systems. Coffee Sci. 8(3):379-388.

Ricci MSF, Costa JR, Pinto AN, Santos VLS (2006) Organic cultivation of coffee cultivars grown under full sun and under shading. Pesqui Agropecu Bras. 41(4):569-575. 
Rodrigues WP, Martins MQ, Fortunato AS, Rodrigues AP, Semedo JN, Simões-Costa MC, Pais IP, Leitão AE, Colwell F, Goulao L, Máguas C, Maia R, Partelli FL, Campostrini E, Scotti-Campos P, Ribeiro-Barros AI, Lidon FC, DaMatta FM, Ramalho JC (2016) Long-term elevated air $\left[\mathrm{CO}_{2}\right]$ strengthens photosynthetic functioning and mitigates the impact of supra-optimal temperatures in tropical Coffea arabica and C. canephora species. Glob. Change Biol. doi: 22:415-431.

Ronquim JC, Prado CHBA, Novaes P,Fahl JI, Ronquim CC (2006) Carbon gain in Coffea arabica during clear and cloudy days in the wet season. Exp Agr. 42(2):147-164.

Rubio-De-Casas R, Pérez-Corona E, Manrique E, Quintana JR, García-Verdugo C, Balaguer L (2007) Field patterns of leaf plasticity in adults of the long-lived evergreen Quercus coccifera. Ann Bot-London. 100(2):325-334.

Salgado BG, Macedo RLG, Venturin N, Carvalho VL (2004) Yield of coffee trees mixed with Inga trees and Grevílea in Lavras-MG, Brazil. Agrossilvicultura. 1(2):155-162.

Santos CAF, Leitão AE, Pais IP, Lidon FC, Ramalho JC (2015) Perspectives on the potential impacts of climate changes on coffee plant and bean quality.Emir. J. Food Agric. 27(2):152-163.

Siles P, Harmand JM, Vaast P (2010) Effects of Inga densiflora on the microclimate of coffee (Coffea arabica L.) and overall biomass under optimal growing conditions in Costa Rica. Agroforest Syst. 78(1):269-286.
Silva FAS, Azevedo CAV (2009) Principal components analysis in the software Assistat-statistical assistance. In: World Congress on Computers in Agriculture, 7., 2009, Reno. Proceedings. Reno: American Society of Agricultural and Biological Engineers.

Steiman SA, Idol TB, Bittenbendera HC, Gautzc LC (2011) Shade coffee in Hawai' $i$ - Exploring some aspects of quality, growth, yield, and nutrition. Sci Hort. 128(3):152158

Tabagiba SD, Santos EA, Pezzopane JEM, Reis EF (2010) Coffea canephora seedlings in the under shading and full sun. Engenh Agr. 18(3):219-226.

Valladares F, Sanches-Gomes D, Zavala MA (2006) Quantitative estimation of phenotypic plasticity: birdging the gap between the evolutionary concept and its ecological applications. J Ecol. 94:1103-1116. 